\title{
Three Double Translations from Arabic into Latin by Gerard of Cremona and Dominicus Gundisalvi
}

\author{
Dag Nikolaus Hasse \\ Universität Würzburg
}

Among the many philosophical translations from Arabic into Latin in twelfthcentury Spain, there are some that were translated twice, notably Alkindi's On the Intellect, Alfarabi's Enumeration of the Sciences and Isaac Israeli's On Definitions and Descriptions. ${ }^{1}$ It has often been suggested that the two translators of these three texts were Gerard of Cremona and Dominicus Gundisalvi, the two contemporaries and canons of Toledo cathedral in the later twelfth century. The first part of this paper musters the evidence for these ascriptions in the manuscripts of the translations, that is, in the titles and colophons, and also considers translator attributions in other medieval texts, such as the well-known list of translations by Gerard of Cremona drawn up by his socii. $^{2}$

In all three cases, many verbal parallels between the two translations show that one translation is a revision of the other. But it is not clear which version was first. In the second part of the paper, I shall propose a philological solution to this question.

I will also be concerned with a fourth text, the Liber de causis. Of this famous text, which in Arabic is called The Discourse on the Pure Good (Kalām fi mahd al-hayr), there exists only one version by the translator Gerard of Cremona. But it has been argued that this version is in fact the result of a stylistic revision by another translator, Dominicus Gundisalvi. ${ }^{3}$ I shall come back to this question at the end of this paper.

1 I am grateful for advice from Stefan Georges and Andreas Büttner.

2 For this list see Burnett 2001.

3 Adriaan Pattin, editor of the 1966 edition of the Latin Liber de causis, has argued that the translation by Gerard of Cremona was revised by Dominicus Gundisalvi. He claims that the vocabulary of Gundisalvi is evident in two cases: in the term intellectibilis and in the phrase habent essentiam (Pattin 1966, p. 98). Richard Taylor has argued that this evidence is not conclusive: "There is no evidence to suggest in any substantial way that the translation of the Liber de causis was systematically revised by anyone" (Taylor 1988, p. 80). I am not convinced 
In what follows, I shall discuss the manuscript evidence for Alkindi's On the Intellect, Alfarabi's On the Sciences and Isaac's On Definitions in sequence, focusing on the titles and translators named in the manuscripts. The first text is Alkindi's On the Intellect (Risāla fì l-'aql). This short text, whose main sources are Aristotle, Alexander of Aphrodisias and John Philoponos, discusses four different kinds of intellect, one outside and three inside the soul. This doctrine influenced later authors such as Alfarabi and Avicenna, but also the scholastic discussion. ${ }^{4}$ The two Latin translations of Alkindi's On the Intellect were edited in 1897 by Albino Nagy. One translation, with the incipit Intellexi quod quesivisti de scribendo sermonem, was edited by Nagy with the subtitle "translatum a magistro Gerardo Cremonensi". The other translation, with the incipit Intellexi quod queris scribi tibi sermonem, was edited without any mentioning of the translator. The first translation uses ratio for rendering the Arabic term 'aql ('intellect'), the second intellectus. Nagy's ascription of the De ratione translation to Gerard of Cremona is based on the evidence of one manuscript, as the table below shows. I have tried to check as many titles, colophons, incipts and explicits as possible in a reasonable time by turning to Marie-Thérèse d'Alverny's Codices volume in the Avicenna Latinus series and to the online indices In principio, Manus Online and Manuscripta mediaevalia.

of the intellectibilis argument by Pattin, since the only occurrence of intellectibilis in Gundisalvi's translations is one sentence in Avicenna's De anima on principiis intellectibilibus, where an alternative reading is principiis intelligibilibus (see Van Riet 1968-1972, vol. II, p. 153, manuscript v). For more information on the Latin translation see d'Ancona, Taylor 2003, p. $610-617$.

4 On this work see Adamson 2007, p. 118-127; Rudolph 2012, p. 109. 
1.1 Alkindi, On the Intellect / De ratione ${ }^{5}$

Incipit: Intellexi quod quesivisti de scribendo sermonem ...

Explicit: ... sermo enuntiativus sufficiat.

at least eight manuscripts

\begin{tabular}{|c|c|c|}
\hline Manuscript & Title & Colophon \\
\hline $\begin{array}{l}\text { Admont, Stiftsbibliothek, } \\
578, \text { f. } 34 \mathrm{v}\end{array}$ & $\begin{array}{l}\text { Tractatus Alpharabii de } \\
\text { modis acceptionum huius } \\
\text { nominis ratio }\end{array}$ & - \\
\hline $\begin{array}{l}\text { Baltimore, The Walters Art } \\
\text { Museum, W.66, f. } 240 v- \\
241 \mathrm{~V}\end{array}$ & $\begin{array}{l}\text { Expositio intellectus } \\
\text { secundum sententiam } \\
\text { Platonis et Aristotelis }\end{array}$ & - \\
\hline $\begin{array}{l}\text { Brugge, Hoofdbibliotheek } \\
\text { Biekorf, 424, f. } 3 \text { ogr }\end{array}$ & - & - \\
\hline $\begin{array}{l}\text { Bruxelles, Bibliothèque } \\
\text { royale de Belgique, II } 255^{8} \text {, } \\
\text { f. } 99^{\mathrm{r}-\mathrm{v}}\end{array}$ & $\begin{array}{l}\text { Incipit liber de ratione sive } \\
\text { de formis rationis }\end{array}$ & $\begin{array}{l}\text { Explicit liber de ratione } \\
\text { sive de formis rationis }\end{array}$ \\
\hline $\begin{array}{l}\text { Firenze, Biblioteca } \\
\text { Nazionale Centrale, Conv. } \\
\text { Soppr. G. } 4 \cdot 354 \text {, f. } 111 \mathrm{v}\end{array}$ & - & - \\
\hline $\begin{array}{l}\text { Oxford, Bodleian Library, } \\
\text { Digby } 217 \text {, f. } 115 \mathrm{~V}\end{array}$ & - & - \\
\hline $\begin{array}{l}\text { Paris, Bibliothèque } \\
\text { nationale de France, Latin } \\
6443 \text {, f. } 19 \text { or }\end{array}$ & $\begin{array}{l}\text { Verbum Iacob Alkindi de } \\
\text { intentione antiquorum } \\
\text { in ratione translatum a } \\
\text { magistro Gerardo Cremon- } \\
\text { ensi }\end{array}$ & - \\
\hline $\begin{array}{l}\text { Roma, Biblioteca Angelica, } \\
242 \text {, f. } 18 \mathrm{r}\end{array}$ & $\begin{array}{l}\text { Incipit verbum Iacob } \\
\text { Alchindi de ratione }\end{array}$ & $\begin{array}{l}\text { Explicit verbum Iacob } \\
\text { Alchindi de intentione } \\
\text { antiquorum in ratione }\end{array}$ \\
\hline
\end{tabular}

5 See the Mss listed by Nagy 1897, p. Xxx-XxxI. 
The translator Gerard of Cremona is mentioned in only one manuscript. I am not aware of any significant external evidence; most importantly, the translation is not mentioned in the socii's list of Gerard's translations. The ascription to Gerard of Cremona is not unreasonable, but needs to be treated with some caution; it will find support from the stylistic arguments below.

The other translation does not give the name of a translator in the 21 manuscripts available to me. Its title is De intellectu et intellecto or simply De intellectu.

\subsection{Alkindi, On the Intellect / De intellectu et intellecto}

Incipit: Intellexi quod queris (tibi scribi) sermonem ...

Explicit: ... tantum sermonis de hoc sufficiat.

at least twenty-one manuscripts

\begin{tabular}{|c|c|c|}
\hline Manuscript & Title & Colophon \\
\hline $\begin{array}{l}\text { Cava de' Tirreni, Biblioteca } \\
\text { statale del Monumento } \\
\text { nazionale della Abbazia } \\
\text { Benedettina della Ss. Trin- } \\
\text { ità, } 31 \text {, f. } 234 \text { r-235r }\end{array}$ & - & - \\
\hline $\begin{array}{l}\text { Cesena, Biblioteca Mal- } \\
\text { atestiana, D.xxII.3, f. 2r }\end{array}$ & $\begin{array}{l}\text { Epistola Auerois de intel- } \\
\text { lectu }\end{array}$ & $\begin{array}{l}\text { Hic finis est Epistole } \\
\text { Aueroys de intellectu }\end{array}$ \\
\hline $\begin{array}{l}\text { Città del Vaticano, Bibli- } \\
\text { oteca Apostolica Vaticana, } \\
\text { Barb. lat. } 463, \text { f. } 85^{r-85 v}\end{array}$ & - & - \\
\hline $\begin{array}{l}\text { Città del Vaticano, Bibli- } \\
\text { oteca Apostolica Vaticana, } \\
\text { Vat. lat. 2186, f. } 7 \text { ov-71r }\end{array}$ & $\begin{array}{l}\text { Liber Aliquindi philosophi } \\
\text { de intellectu et intellecto }\end{array}$ & - \\
\hline $\begin{array}{l}\text { Città del Vaticano, Bibli- } \\
\text { oteca Apostolica Vaticana, } \\
\text { Vat. lat. } 4426 \text {, f. } 6 \mathrm{r}-\mathrm{v}\end{array}$ & $\begin{array}{l}\text { Incipit liber Alkindi de } \\
\text { intellectu }\end{array}$ & $\begin{array}{l}\text { Explicit liber Alkindi de } \\
\text { intellectu }\end{array}$ \\
\hline $\begin{array}{l}\text { Erfurt, Universitätsbiblio- } \\
\text { thek, CA } 2^{\circ} 29 \text {, f. } 210 r-v\end{array}$ & - & - \\
\hline $\begin{array}{l}\text { Erfurt, Universitätsbiblio- } \\
\text { thek, CA } 4^{\circ} 15, \text { f. } 54 \mathrm{~V}^{-} 55^{\mathrm{r}} \\
\text { and } 55^{\mathrm{V}}\end{array}$ & Libellus de intellectibus & - \\
\hline $\begin{array}{l}\text { Graz, Universitätsbiblio- } \\
\text { thek, } 482 \text {, f. } 234 \mathrm{r}-\mathrm{v}\end{array}$ & - & - \\
\hline
\end{tabular}


(cont.)

\begin{tabular}{|c|c|c|}
\hline Manuscript & Title & Colophon \\
\hline $\begin{array}{l}\text { København, Det Kongelige } \\
\text { Bibliotek, Thott } 1642^{\circ} \text {, } \\
\text { f. } 117 \mathrm{r}-\mathrm{v}\end{array}$ & De intellectu & - \\
\hline $\begin{array}{l}\text { Lisboa, Biblioteca Nacional } \\
\text { de Portugal, Fondo Geral } \\
\text { 2299, f. } 171 \mathrm{r}-\mathrm{v}\end{array}$ & - & - \\
\hline ibid., f. 208r-v & - & - \\
\hline $\begin{array}{l}\text { Modena, Biblioteca } \\
\text { Estense Universitaria, Lat. } \\
296 \text { = alfa.M.8.21, f. } 35^{\mathrm{V}-36 \mathrm{r}}\end{array}$ & - & - \\
\hline $\begin{array}{l}\text { München, Bayerische } \\
\text { Staatsbibliothek, Clm 8oo1, } \\
\text { f. 114r-v }\end{array}$ & - & - \\
\hline $\begin{array}{l}\text { Oxford, Bodleian Library, } \\
\text { Digby } 217 \text {, f. } 178 \mathrm{r}-\mathrm{v}\end{array}$ & - & - \\
\hline $\begin{array}{l}\text { Oxford, Merton College } \\
\text { Library, 278, f. 183v }\end{array}$ & - & - \\
\hline $\begin{array}{l}\text { Paris, Bibliothèque } \\
\text { nationale de France, Latin } \\
6443, \text { f. } 195^{r}\end{array}$ & $\begin{array}{l}\text { Liber Alquindi philosophi } \\
\text { de intellectu et intellecto }\end{array}$ & - \\
\hline $\begin{array}{l}\text { Paris, Bibliothèque } \\
\text { nationale de France, Latin } \\
\text { 166o2, f. 111r-111v }\end{array}$ & $\begin{array}{l}\text { Liber Alexandri de intel- } \\
\text { lectu }\end{array}$ & - \\
\hline $\begin{array}{l}\text { Paris, Bibliothèque } \\
\text { nationale de France, Latin } \\
\text { 16613, f. 10or-101r }\end{array}$ & $\begin{array}{l}\text { De intellectu secundum } \\
\text { Aristotelem et Platonem }\end{array}$ & $\begin{array}{l}\text { Explicit liber de intellectu } \\
\text { et intellecto secundum } \\
\text { Alpharabium }\end{array}$ \\
\hline $\begin{array}{l}\text { Uppsala, Universitetsbibli- } \\
\text { otek, C } 595 \text {, f. } 24 \mathrm{v}-25^{\mathrm{r}}\end{array}$ & - & - \\
\hline $\begin{array}{l}\text { Venezia, Biblioteca } \\
\text { Nazionale Marciana, Lat. } \\
\text { VI, } 150(=2671) \text {, f. } 64 \mathrm{r}\end{array}$ & - & - \\
\hline $\begin{array}{l}\text { Worcester, Cathedral Lib- } \\
\text { rary, Q. 81, f. 84v }\end{array}$ & $\begin{array}{l}\text { Liber Alquindi philosophi } \\
\text { de intellectu et intellecto }\end{array}$ & - \\
\hline
\end{tabular}


Gundisalvi's own works De divisione philosophiae and Liber de anima do not quote this translation, to the best of my knowledge, and I am not aware of quotations in other works by Gundisalvi either.

The second double translation is of Alfarabi's famous Enumeration of the Sciences (Ihṣa $\bar{a}^{\prime}$ al-ulüm), which was important for the intellectual development of the Latin West in several respects: because it offered a systematic and broad division of the sciences, many of which were not known in the Latin West; because it measured all sciences against the ideal of demonstrative reasoning; ${ }^{6}$ and because it apparently prompted a good number of translators in twelfthand thirteenth-century Spain to fill in the gaps in the Latin spectrum of sciences by producing new translations from Arabic. ${ }^{7}$

One of the two translations stems from Gerard of Cremona. This we know from the students' list, which contains the entry Liber Alfarabii de scientiis among Gerard's philosophical translations. Moreover, the translation with the incipit Nostra in hoc libro intentio is ascribed to Gerard of Cremona in two of the four manuscripts extant.

\subsection{Alfarabi, Enumeration of the Sciences / De scientiis}

Incipit: Nostra in hoc libro intentio est scientias famosas ...

Explicit: ... sicut fit mulieribus et infantibus.

at least four manuscripts

\begin{tabular}{lll}
\hline Manuscript & Title & Colophon \\
\hline $\begin{array}{l}\text { Admont, Stiftsbibliothek, } \\
578, \text { f. 27r-33r }\end{array}$ & $\begin{array}{l}\text { Incipit liber Alpharabii de } \\
\text { divisione scienciarum }\end{array}$ & $\begin{array}{l}\text { Completus est liber } \\
\text { Alpharabii vel Albunazir } \\
\text { de scienciis }\end{array}$ \\
$\begin{array}{ll}\text { Brugge, Hoofdbibliotheek } \\
\text { Biekorf, 486, f. 94r-110v }\end{array}$ & $\begin{array}{l}\text { Liber Alfarabii de sci- } \\
\text { entiis translatus a magistro } \\
\text { Gerardo Cremonensi de } \\
\text { arabico in latinum }\end{array}$ \\
\end{tabular}

6 See Hasse 2020, ch. 2, with further literature.

7 Burnett 2001. 
(cont.)

\begin{tabular}{lll}
\hline Manuscript & Title & Colophon \\
\hline $\begin{array}{ll}\text { Graz, Universitätsbiblio- } \\
\text { thek, 482, f. 222v-229r }\end{array}$ & - & $\begin{array}{l}\text { Completus est liber } \\
\text { Alfrabii vel Abunazir de } \\
\text { sentenciis }\end{array}$ \\
$\begin{array}{l}\text { Paris, Bibliothèque } \\
\text { nationale de France, Latin } \\
\text { 9335, f. 143va-151vb }\end{array}$ & $\begin{array}{l}\text { Liber Alfarabii de scientiis } \\
\text { translatus a magistro Gir- } \\
\text { ardo Cremonensi in Toleto }\end{array}$ \\
& $\begin{array}{l}\text { de arabico in Latinum } \\
\end{array}$ & \\
\hline
\end{tabular}

The other translation, with the incipit Cum plures essent, is extant in at least nine manuscripts. As the below list of titles and colophons shows, the treatise is most commonly called De divisione scientiarum and is clearly identified as being written by Alfarabi. But none of the manuscripts mentions the name of the translator. This needs to be emphasized, as an antidote against the optimistic titles given to the treatise by modern editors: Manuel A. Alonso edited the text as Domingo Gundisalvo: De scientiis, compilación a base principalmente de la Maqāla fì iḥ̣ă̄ al-ulūm de al-Fārābū, and Jakob H.J. Schneider under AlFārābī:De scientiis secundum versionem Dominici Gundisalvi, where the phrase secundum versionem is Schneider's own Latin creation. This is not wrong, as we shall see, but it is not how medieval readers knew the text.

\subsection{Alfarabi, On the Sciences / De divisione scientiarum}

Incipit: Cum plures essent (olim) philosophi ...

Explicit: ... alia in operationibus.

at least nine manuscripts

\begin{tabular}{lll}
\hline Manuscript & Title & Colophon \\
\hline $\begin{array}{l}\text { Cambridge, Fitzwilliam } \\
\text { Museum, McClean } 169\end{array}$ & - & libellus Alph. de diu. sci. \\
$(16)$, f. 24 or-246r & \\
$\begin{array}{l}\text { Erfurt, Universitätsbiblio- } \\
\text { thek, CA } 2^{\circ} 32, \text { f. } 79 r-88 \mathrm{r}\end{array}$ & $\begin{array}{l}\text { Liber Alphorabii de propri- } \\
\text { etatibus scientiarum valde } \\
\text { bonus }\end{array}$ \\
&
\end{tabular}




\begin{tabular}{|c|c|c|}
\hline Manuscript & Title & Colophon \\
\hline $\begin{array}{l}\text { Erfurt, Universitätsbiblio- } \\
\text { thek, CA } 4^{\circ} 295 \text {, f. } 24 \mathrm{r}-35^{\mathrm{r}}\end{array}$ & $\begin{array}{l}\text { Incipit liber Alforabii de } \\
\text { divisione scientiarum }\end{array}$ & - \\
\hline $\begin{array}{l}\text { Lisboa, Biblioteca Nacional } \\
\text { de Portugal, Fondo Geral } \\
\text { 2299, f. } 165 \text { va-169vb }\end{array}$ & De divisione scientiarum & - \\
\hline $\begin{array}{l}\text { London, British Library, } \\
\text { Cotton Vespasian B X } 5 \text {, } \\
\text { f. } 24 \mathrm{ra}-27 \mathrm{rb}\end{array}$ & $\begin{array}{l}\text { Incipit Alpharabius de } \\
\text { divisione omnium scien- } \\
\text { tiarum }\end{array}$ & $\begin{array}{l}\text { Explicit liber Alpharabii de } \\
\text { divisione omnium scien- } \\
\text { tiarum }\end{array}$ \\
\hline $\begin{array}{l}\text { Oxford, Merton College } \\
\text { Library, 23o, f. 29ra-32ra }\end{array}$ & - & - \\
\hline $\begin{array}{l}\text { Wien, Bibliothek des } \\
\text { Dominikanerkonvents, } \\
15^{1} \text { (olim 121), f. 132r-133V }\end{array}$ & $\begin{array}{l}\text { Alpharabi de divisione } \\
\text { scientiarum }\end{array}$ & $\begin{array}{l}\text { Explicit Alpharabi de divi- } \\
\text { sione scientiarum }\end{array}$ \\
\hline $\begin{array}{l}\text { Wien, Österreichische } \\
\text { Nationalbibliothek, 2473, } \\
\text { f. 1a-29b }\end{array}$ & $\begin{array}{l}\text { Alpharabius iurisconsultus } \\
\text { de origine scientiarum }\end{array}$ & - \\
\hline $\begin{array}{l}\text { Worcester, Cathedral Lib- } \\
\text { rary, Q. } 81, \text { f. } 85^{\mathrm{r}-87 \mathrm{~V}}\end{array}$ & Liber Alfarabi de scientiis & - \\
\hline
\end{tabular}

The anonymous Cum plures essent version is the main source of Dominicus Gundisalvi's own treatise De divisione philosophiae, which also draws on other sources by Avicenna and al-Ġazālī. ${ }^{8}$

The third double translation is of the treatise On Definitions and Descriptions (Kitāb al-Hudūd wa-r-rusūm) by Isaac Israeli, the philosopher and physician who was active in Qayrawān in North Africa in the early tenth century and makes much use of writings by Alkindi. One can say with great certainty that one of the two translations comes from Gerard of Cremona. The translation with the incipit Plures eorum qui is attributed to Gerard in two of the at least 16 manuscripts. It seems that this translation traveled under two titles: a short title, which is Liber de diffinitionibus, and a long title, which involves the phrases

8 See Fidora, Werner 2007. For a convenient juxtaposition of Gerard's version, the Cum plures essent version and of Gundisalvi's own De divisione philosophiae on the metaphysical science, see Polloni 2016, p. 100-106. 
Collections from the sayings of the philosophers and About the difference between definition and description. These phrases appear also in an Arabic-Hebrew translation and apparently belonged to the original Arabic title, which is lost. ${ }^{9}$ The long title has close verbal parallels with the entry in the socii's list of Gerard's translation: Liber Ysac de descriptione rerum et diffinitionibus earum et de differentia inter descriptionem et diffinitionem..$^{10}$ This again supports the ascription of the translation to Gerard.

\subsection{Isaac Israeli, On Definitions / Liber de diffinitionibus}

Incipit: Plures eorum qui antiquorum libros inspexerunt ...

Explicit: ... testificatur illius contrarium.

at least sixteen manuscripts

\begin{tabular}{|c|c|c|}
\hline Manuscript & Title & Colophon \\
\hline $\begin{array}{l}\text { Bernkastel-Kues, Biblio- } \\
\text { thek des Cusanusstifts, } \\
205 \text {, f. } 121 \mathrm{r}-\mathrm{v}\end{array}$ & $\begin{array}{l}\text { Collectiones hee sunt ex } \\
\text { dictis philosophorum ... }\end{array}$ & $\begin{array}{l}\text { Explicit liber deffinitionum } \\
\text { Ysaac }\end{array}$ \\
\hline $\begin{array}{l}\text { Bologna, Biblioteca del } \\
\text { Collegio di Spagna, 103, } \\
\text { f. IIIra-IVvb }\end{array}$ & - & - \\
\hline $\begin{array}{l}\text { Città del Vaticano, Bibli- } \\
\text { oteca Apostolica Vaticana, } \\
\text { Vat. lat. } 2186 \text {, f. } 46 \mathrm{v}-5 \text { or }\end{array}$ & - & - \\
\hline $\begin{array}{l}\text { Kraków, Biblioteka Jagiel- } \\
\text { lońska, 816, f. 1r-6v }\end{array}$ & - & - \\
\hline $\begin{array}{l}\text { Lisboa, Biblioteca Nacional } \\
\text { de Portugal, Fondo Geral } \\
\text { 2299, f. } 3 \text { o1v-3o7r }\end{array}$ & - & - \\
\hline $\begin{array}{l}\text { Mainz, Wissenschaftliche } \\
\text { Stadtbibliothek, I 519, } \\
\text { f. } 114 \mathrm{~V}-118 \mathrm{r}\end{array}$ & $\begin{array}{l}\text { Collectis ex dictis philoso- } \\
\text { phorum ... }\end{array}$ & - \\
\hline $\begin{array}{l}\text { Olomouc, Státní okresní } \\
\text { archiv, C O 536, f. 1or-13v }\end{array}$ & $\begin{array}{l}\text { Incipiunt diffinitiones } \\
\text { Ysaac ... filii Salomonis. }\end{array}$ & - \\
\hline
\end{tabular}

$9 \quad$ Altmann, Stern 1958, p. 11, fn.

10 Burnett 2001, p. 280. 


\begin{tabular}{|c|c|c|}
\hline Manuscript & Title & Colophon \\
\hline & $\begin{array}{l}\text { Collectiones ex dictis } \\
\text { philosophorum de dif- } \\
\text { ferentia inter descriptiones } \\
\text { et diffinitiones rerum et } \\
\text { quare philosophia fuit } \\
\text { descripta et non diffinita. } \\
\text { De quorum aggregatione et } \\
\text { ordinatione Ysaac medicus } \\
\text { sollicitus fuit. Verba Ysaac }\end{array}$ & - \\
\hline $\begin{array}{l}\text { Oxford, Bodleian Library, } \\
\text { Digby } 217, \text { f. } 111 \mathrm{r}-115^{\mathrm{V}}\end{array}$ & $\begin{array}{l}\text { Incipit liber Isaac de diffin- } \\
\text { itionibus translatus a } \\
\text { magistro G. Cremon. in } \\
\text { Toleto }\end{array}$ & - \\
\hline $\begin{array}{l}\text { Paris, Bibliothèque de } \\
\text { l'Arsenal, 75o, f. 99rb- } \\
\text { 1o1vb }\end{array}$ & $\begin{array}{l}\text { Incipit liber de diffini- } \\
\text { tionibus Ysaac }\end{array}$ & - \\
\hline $\begin{array}{l}\text { Paris, Bibliothèque } \\
\text { nationale de France, Latin } \\
6443 \text {, f. } 187 \mathrm{r}-19 \text { or }\end{array}$ & $\begin{array}{l}\text { Liber Ysaac de diffin- } \\
\text { itionibus translatus a } \\
\text { magistro G. Cremonensi } \\
\text { in Toleto }\end{array}$ & $\begin{array}{l}\text { Finiuntur collectiones } \\
\text { Ysaac Israelite medici } \\
\text { in descriptionibus } \\
\text { rerum et diffinitionibus } \\
\text { earum et differentia } \\
\text { inter descriptionem et } \\
\text { diffinitionem }\end{array}$ \\
\hline $\begin{array}{l}\text { Paris Bibliothèque } \\
\text { nationale de France, Latin } \\
\text { 1470o, f. } 153^{\mathrm{r}-16 \text { ov }}\end{array}$ & $\begin{array}{l}\text { Collectiones ex dictis } \\
\text { philosophorum de differ- } \\
\text { encia inter descripciones } \\
\text { rerum et definiciones } \\
\text { earum et quare philo- } \\
\text { sophia fuit descripta } \\
\text { et non definita; de } \\
\text { quorum aggregacione et } \\
\text { ordinacione Isaac medicus } \\
\text { filius Salomonis sollicitus } \\
\text { fuit. Verba Ysaac }\end{array}$ & $\begin{array}{l}\text { Finiuntur collectiones } \\
\text { Ysaac Israelite medici } \\
\text { in descriptionibus } \\
\text { rerum et diffinitionibus } \\
\text { earum et differentia } \\
\text { inter descriptionem et } \\
\text { diffinitionem }\end{array}$ \\
\hline
\end{tabular}


(cont.)

\begin{tabular}{|c|c|c|}
\hline Manuscript & Title & Colophon \\
\hline $\begin{array}{l}\text { Paris, Bibliothèque Sainte- } \\
\text { Geneviève, 2236, f. 106r- } \\
\text { 116r }\end{array}$ & $\begin{array}{l}\text { Incipit liber de diffini- } \\
\text { cionibus Ysach }\end{array}$ & - \\
\hline $\begin{array}{l}\text { Praha, Národní knihovna } \\
\text { České republiky, } 2364 \\
\text { (xıIı.F.26), f. 59r-65V }\end{array}$ & - & - \\
\hline $\begin{array}{l}\text { Roma, Biblioteca Angelica, } \\
242 \text {, f. } 2 \mathrm{OV}-24 \mathrm{r}\end{array}$ & $\begin{array}{l}\text { Incipit liber diffinitionum } \\
\text { et descriptionum Ysaac } \\
\text { summi philosophy }\end{array}$ & - \\
\hline $\begin{array}{l}\text { Uppsala, Universitetsbibli- } \\
\text { oteket, C } 659 \text {, f. } 114 \mathrm{v}-118 \mathrm{r}\end{array}$ & $\begin{array}{l}\text { Collectum ex dictis philo- } \\
\text { sophorum de differentia }\end{array}$ & - \\
\hline $\begin{array}{l}\text { Weimar, Herzogin Anna } \\
\text { Amalia Bibliothek, Fol. 61, } \\
\text { f. 9ov-94v }\end{array}$ & $\begin{array}{l}\text { Collectiones ex dictis phyl- } \\
\text { osophorum de differencia } \\
\text { inter descriptiones rerum } \\
\text {... }\end{array}$ & Explicit liber diffinitionum \\
\hline
\end{tabular}

The second Isaac translation with the incipit Quamplures in libris is transmitted in at least six manuscripts, and hence less often than Gerard's version. Its title is De diffinitionibus. The manuscripts do not mention any translator.

\subsection{Isaac Israeli, On Definitions / De diffinitionibus}

Incipit: Quamplures (invenientes) in libris philosophorum ...

Explicit: ... resolutionem ex motu.

at least six manuscripts

\begin{tabular}{lll}
\hline Manuscript & Title & Colophon \\
\hline $\begin{array}{l}\text { Cambridge, St. John's } \\
\text { College Library, 120 IV, }\end{array}$ & - & - \\
f. 178r-182r & \\
$\begin{array}{l}\text { Edinburgh, University Lib- } \\
\text { rary, } 134, \text { f. } 34 \mathrm{v}-36 \mathrm{v}\end{array}$ & $\begin{array}{l}\text { Incipit liber Isaac de diffin- } \\
\text { itionibus }\end{array}$
\end{tabular}




\begin{tabular}{lll}
\hline Manuscript & Title & Colophon \\
\hline $\begin{array}{lll}\text { Erfurt, Universitätsbiblio- } \\
\text { thek, CA } 2^{\circ} 3^{2} \text {, f. 88v-92v }\end{array}$ & - & - \\
$\begin{array}{l}\text { München, Bayerische } \\
\text { Staatsbibliothek, Clm 8oo1, }\end{array}$ & $\begin{array}{l}\text { Incipit Ysaac de diffini- } \\
\text { f. 151v-154v }\end{array}$ & Explicit Ysaac \\
Oxford, Corpus Christi & Incipit liber Ysaac de & Explicit Ysaac de diffini- \\
College Library, 86, f. 219v- & diffinitionbus & tionibus et descriptionibus \\
224r & & \\
Wien, Bibliothek des & Ysaac de diffinitionibus & - \\
Dominikanerkonvents, & & \\
151 (121), f. 133v-135r & & \\
\end{tabular}

Dominicus Gundisalvi silently quotes from this version of Isaac's On Definitions in his Liber de anima and his De divisione philosophiae. ${ }^{11}$ This is very indicative, but it does not yet prove that Gundisalvi was the translator of the version. It only shows that the translation predates the composition of the two treatises by Gundisalvi.

As to Gundisalvi as the translator of the three anonymous versions, we are on firmer ground with the stylistic evidence for translator attribution that I have presented in the article "Notes on Anonymous Twelfth-Century Translations", published together with Andreas Büttner, which focuses on philosophical translations from Arabic into Latin on the Iberian Peninsula. The analysis of small words and phrases specific to known translators leads to the result that it is probable that the anonymous version of all three texts, i.e. Alkindi's $O n$ the Intellect, Alfarabi's Enumeration and Isaac's On Definitions, was produced by Dominicus Gundisalvi. ${ }^{12}$ This result will be corroborated by the present paper, in particular by the last table below which lists Gundisalvian vocabulary that distinguishes Gundisalvi from Gerard.

\footnotetext{
11 Muckle 1940, p. 98 (De anima) and Fidora, Werner 2007, p. 56-6o (De divisione philosophiae).

12 Hasse, Büttner 2018, p. 338-341.
} 
Gerard of Cremona and Dominicus Gundisalvi were contemporaries, and both were canons of the cathedral of Toledo: Gerard is mentioned in three charters of the cathedral in 1157, 1174 and 1176. He dies in 1187. Gundsalvi appears in charters between 1162 and 119o. The dates of their lives, therefore, do not settle the question of who was translating first.

The issue of the priority of the two versions has often been discussed, especially with respect to Alfarabi's On the Sciences. ${ }^{13}$ Gerard's version of this text is a literal translation; Gundisalvi's translation is shorter, less than half the length of Gerard's translation, and leaves out, among other things, topics touching on the religion of Islam and on Arabic grammar. Manuel Alonso, ${ }^{14}$ Richard Lemay, ${ }^{15}$ Jacob H.J. Schneider, ${ }^{16}$ Alain Galonnier ${ }^{17}$ and others have suggested that Gundisalvi's shorter version was the earlier one. They argue that Gundisalvi's translation is a Latin digest or compendium of the Arabic original, and that Gerard later decided he wanted to have a literal and complete version.

In contrast, Michael C. Weber, ${ }^{18}$ Franz Schupp ${ }^{19}$ and others have argued that Gerard was first and that Gundisalvi later revised Gerard's text, leaving out passages he did not find relevant. One reason advanced for Gundisalvi being the reviser is that his vocabulary is believed to be more up-to-date, more current in the philosophy of the twelfth century: Gundisalvi writes essentia instead of existentia, practica instead of activa, theorica instead of speculativa. ${ }^{20}$ But Richard Lemay argues that Gerard of Cremona consciously avoids certain vocabulary and that he did this when correcting Gundisalvi's early and incomplete translation. ${ }^{21}$ As one can see, the issue is not settled by these arguments. Both stories are possible: that Gerard found Gundisalvi's shorter translation deficient and decided to complete it. Or that Gundisalvi took Gerard's

13 See the summary of the discussion in Schupp 2005, p. LXIII-LXIV.

14 Alonso 1954, p. 13-32. Cf. also Farmer 196o, p. 19-20, who believes that Gerard of Cremona revised the translation by Gundisalvi (which he believes to be by "John of Seville") because he was concerned about the omissions and wanted to be more faithful to the Arabic.

15 Lemay 1978, p. 175 and 181-182.

16 Schneider 2006, p. 116-117.

17 Galonnier 2016, p. 78-79.

18 Weber 2002, p. 131-132. Another scholar who advocates the priority of Gerard's version, is Jolivet 1988, p. 135-136. Burnett 2001, p. 269, leaves the matter open.

19 Schupp 2005, p. LXIV.

20 Schupp 2005, p. LXIV.

21 See $n .15$ above. 
literal translation and transformed it into something more understandable for the Latin reader.

My idea of a philological solution to the question is best explained by turning to an example, a passage from Alkindi's On the Intellect. The following table offers a synopsis of the two Latin versions by Gerard and Gundisalvi, as edited by Nagy:22

Alkindi, On the Intellect

\begin{tabular}{|c|c|}
\hline & Anonymous (Gundisalvi) \\
\hline 1 & ratio \\
\hline 2 & igitur \\
\hline 3 & intellectus \\
\hline 4 & et \\
\hline 5 & rationatum|intellectum \\
\hline 6 & sunt \\
\hline 7 & \begin{tabular}{r|l} 
res una ex parte animae. & unum secundum quod sunt in \\
Ratio & anima. Intellectus
\end{tabular} \\
\hline 8 & uero \\
\hline 9 & quae $\mid$ qui \\
\hline 10 & est \\
\hline 11 & in \\
\hline 12 & actu semper \\
\hline 13 & faciens extrahere et qui extrahit \\
\hline 14 & animam ad hoc ut fiat \\
\hline 15 & rationalis actu|in effectu intelligens \\
\hline 16 & postquam fuerat \\
\hline 17 & rationalis|intelligens in \\
\hline 18 & potentia, \\
\hline 19 & ipse et intellectum ipsum \\
\hline 20 & non \\
\hline 21 & est ipsa et rationatum $\mid$ sunt \\
\hline 22 & res \\
\hline 23 & una. Rationatum|una. Intellectum \\
\hline 24 & igitur in anima et \\
\hline
\end{tabular}

22 The table was created with a computer programme written by my Würzburg colleague Andreas Büttner. 
Alkindi, On the Intellect (cont.)

\begin{tabular}{lc|c}
\hline & Gerard of Cremona & Anonymous (Gundisalvi) \\
\hline 25 & ratio prima $\mid$ intellectus primus \\
26 & exparte \\
27 & rationis $\mid$ intelligentiae \\
28 & primae non \\
29 & est $\mid$ sunt \\
30 & res una \\
\hline
\end{tabular}

The column on the left contains Gerard's version, the column on the right Gundisalvi's. In some parts, both versions have the same text, which is when the line of the table is not divided into two columns. Line 14, for instance, only contains the words animam ad hoc ut fiat, which appear in both versions. In the following line 15, the two versions differ: Gerard writes rationalis actu where Gundisalvi has in effectu intelligens. Line 16 is again identical in both versions: postquam fuerat. It is very clear from this table that the two versions share a good amount of text and that one version is a revision of the other. But which was first?

The problem can be solved, I suggest, by concentrating on the text shared by both translators: that is, the lines without a break in the middle, the text which is common ground, which is unrevised and hence clearly part of the earlier translation. Does it contain the vocabulary of Gerard or of Gundisalvi? This is the crucial question.

The table above with a passage of Alkindi's On the Intellect gives first hints towards an answer. In line 7 of the table, Gerard of Cremona writes ex parte, where Gundisalvi has secundum quod sunt in, translating the Arabic min ğiha, 'with respect to', or 'from the perspective of'. ${ }^{23}$ The two different renderings appear again in another passage of the text (not quoted here). But in line 26, the text is unchanged: ex parte appears in both versions. This is an indication that ex parte is Gerard's vocabulary and that it comes from the original translation.

This, of course, is only a single passage. It is advisable to base stylistic arguments on a systematic approach to make them convincing. In the following, this is attempted in three methodical steps: first, by focusing on words and phrases highly characteristic of Gerard of Cremona or Dominicus Gundisalvi if

23 Abū Rīda 1950-1953, p. $35^{6}$ and 357. The other passage is on p. 355; here ex parte and secundum quod sunt in translate ammā ... fa ('as to'). 
compared against other Arabic-Latin translators of the twelfth century on the Iberian Peninsula; second, by focusing on the vocabulary that distinguishes the translations of Gerard of Cremona from those of Dominicus Gundisalvi; and third, by focusing on words and phrases that the common ground shares with one of the two versions. In other words, the three approaches search for stylistic evidence in the common ground by comparing its vocabulary to three sets of texts of decreasing size: comparing, first, against the translations of other persons; second, against other translations by Gerard and Gundisalvi; and third, against the individual versions of the three double translations.

(1) Let us start with the words singled out as highly characteristic of Gerard or Gundisalvi. In the above-mentioned paper "Notes on Anonymous TwelfthCentury Translations", about 5 o words and phrases were isolated for Gerard and Gundisalvi respectively as being exclusively characteristic for them if analyzed as part of a set of 29 philosophical translations and 23 astronomical and astrological translations of the twelfth century. Do any of these highly characteristic words reappear in the common ground of the three double translations? The answer is presented in the following table: ${ }^{4}$

Gerard's and Gundisalvi's translations compared against other translators

\begin{tabular}{|c|c|c|}
\hline & $\begin{array}{l}\text { Gerard of Cremona: } \\
\text { stylistic words } \\
\text { in the common ground }\end{array}$ & $\begin{array}{l}\text { Dominicus Gundisalvi: } \\
\text { stylistic words } \\
\text { in the common ground }\end{array}$ \\
\hline Alkindi, On the Intellect & sunt res una (1) & - \\
\hline Alfarabi, On the Sciences & - & - \\
\hline Isaac Israeli, On Definitions & $\begin{array}{l}\text { reliquarum (1), absque } \\
\text { medio (1), eius et ipsius (1) }\end{array}$ & - \\
\hline
\end{tabular}

While there are no words specific to Gundisalvi in the common ground, we encounter one phrase specific to Gerard in Alkindi and three such Gerardian phrases in Isaac Israeli. One phrase in Alkindi, of course, is not very strong evidence, even in a short text, but the three highly characteristic phrases in Isaac are significant. This is a first robust indication that the common ground of the

24 The word count is based on the following editions of the Latin versions: Nagy 1897, p. 1-11, for On the Intellect; Schupp 2005 and Schneider 2006 for On the Sciences; Muckle 1937-1938 for On Definitions. 
two Isaac Israeli translations is the work of Gerard and not of Gundisalvi. Also, it makes us wonder whether Gundisalvi was involved in the production of the common ground at all.

(2) In a next step, we do not consider the other translators of the century any more, but concentrate on terms and phrases that distinguish between the translations of Gerard and Gundisalvi only. The corpus on which this search is based contains eight translations by Gerard and seven by Gundisalvi, all in the field of philosophy. ${ }^{25}$ I have split up each of the double translations into three files, in the manner of the table above with the ex parte-passage from Alkindi's On the Intellect, which was divided into three columns. One file contains the common ground, one file the text isolated for Gerard, one file the text isolated for Gundisalvi. As the table below shows, Gundisalvi's isolated texts are shorter than Gerard's - with the exception of Alkindi's On the Intellect, where they have about the same length — but they are still long enough to be useful for stylistic analysis.

\begin{tabular}{lccccc}
\hline & $\begin{array}{c}\text { Gerard's } \\
\text { translation }\end{array}$ & $\begin{array}{c}\text { Gerard's } \\
\text { isolated } \\
\text { text }\end{array}$ & $\begin{array}{c}\text { Common } \\
\text { ground }\end{array}$ & $\begin{array}{c}\text { Anonymous's } \\
\text { (Gundisalvi's) } \\
\text { isolated text }\end{array}$ & $\begin{array}{c}\text { Anonymous } \\
\text { Translation } \\
\text { (Gundisalvi) }\end{array}$ \\
\hline $\begin{array}{l}\text { Alkindi, On the } \\
\text { Intellect }\end{array}$ & 733 words & 358 & 375 & 430 & 805 \\
$\begin{array}{l}\text { Alfarabi, On } \\
\text { the Sciences }\end{array}$ & 15106 & 11994 & 3112 & 3788 & 6900 \\
$\begin{array}{l}\text { Isaac Israeli, } \\
\text { On Definitions }\end{array}$ & 7124 & 4624 & 2500 & 1952 & 4452 \\
\hline
\end{tabular}

I have then started to search, with a search software written by Andreas Büttner, for all those terms in Alkindi's On the Intellect which are both in Gerard's isol-

25 The corpus consists of the following translations: Gerard of Cremona's translations of Aristotle, Analytica posteriora; Aristotle, De caelo; Aristotle / Ibn al-Bițrīq, Meteora I-III; Ps.-Aristotle, Liber de causis; Alexander of Aphrodisias, De tempore, De sensu, De eo quod augmentum; Themistius, Comm. on Analytica posteriora; Alkindi, De quinque essentiis; and Alkindi, De somno et visione; as well as Dominicus Gundisalvi's translations (partly produced together with collaborators) of Avicenna, De anima; Avicenna, De medicinis cordialibus; Ibn Gabirol, Fons vitae; Algazel, Summa theoricae philosophiae; Avicenna, Philosophia prima; Avicenna, De convenientia et differentia scientiarum; Ps.-Avicenna, Liber celi et mundi. 
ated text and in the common ground, but not in Gundisalvi's isolated text and not in any of Gundisalvi's seven translations either. This I did for Alfarabi and Isaac Israeli too, and then repeated the procedure for Gundisalvi: I searched for vocabulary of Gundisalvi's isolated text which is in the common ground, but not in Gerard's isolated text nor in any of Gerard's translations in the corpus either. The aim of this approach is to see whether any vocabulary of the original translation, which is untypical of the other translator, survived in the common ground. The result is presented in the table below. ${ }^{26}$

It proves a sensible procedure to extinguish all those terms that are used in the other philosophical translations by Gerard and Gundisalvi. The phrase $e x$ parte, for instance, which we met above, does not appear in the table below, even though it seemed clear that Gundisalvi twice changed Gerard's phrase ex parte into secundum quod sunt in and once left ex parte untouched. In fact, however, ex parte belongs to Gundisalvi's regular vocabulary in other translations, and the (low) possibility remains that Gundisalvi wrote both secundum quod sunt and ex parte in the common ground. This is why in this second approach the focus is on vocabulary that reappears in the common ground, but not in the other translations of the rival translator.

Note that the vocabulary in this table-other than in the first approach above-is not purely stylistic, but contains many content words that are specific to single disciplines, such as pondera ("weights") or civitates ("states").

Gerard's translations compared against Gundisalvi's translations

\begin{tabular}{|c|c|c|}
\hline & $\begin{array}{l}\text { Gerard of Cremona: } \\
\text { vocabulary from Gerard's isolated text } \\
\text { untypical of Gundisalvi in the common } \\
\text { ground }\end{array}$ & $\begin{array}{l}\text { Dominicus Gundisalvi: } \\
\text { vocabulary from Gun- } \\
\text { disalvi's isolated text } \\
\text { untypical of Gerard in } \\
\text { the common ground }\end{array}$ \\
\hline $\begin{array}{l}\text { Alkindi, On } \\
\text { the Intellect }\end{array}$ & $\begin{array}{l}\text { sermonis ( } 2 \text { occ. in Gerard's isolated text } / 1 \\
\text { occ. in the common ground) }\end{array}$ & $\begin{array}{l}\text { effectum }(3 / 1) \text {, exit } \\
(2 / 2)\end{array}$ \\
\hline $\begin{array}{l}\text { Alfarabi, On } \\
\text { the Sciences }\end{array}$ & $\begin{array}{l}\text { sermones }(24 / 1) \text {, declarat }(11 / 3) \text {, civitati- } \\
\text { bus }(10 / 3) \text {, pondera }(6 / 1) \text {, erret }(6 / 1) \text {, gentis } \\
(5 / 1) \text {, conditiones }(5 / 1) \text {, ponderum }(3 / 1) \text {, } \\
\text { uteretur }(3 / 1) \text {, inimicus }(3 / 1) \text {, propalavit }\end{array}$ & $\begin{array}{l}\text { de dictionibus }(5 / 2) \text {, est } \\
\text { proprium }(4 / 1)\end{array}$ \\
\hline
\end{tabular}

26 The table lists terms or phrases that appear at least twice in the isolated texts. Not included are two-word phrases with $e t$, which are legion and of doubtful stylistic value. 
Gerard's translations compared against Gundisalvi's translations (cont.)

\begin{tabular}{ll}
\hline Gerard of Cremona: & $\begin{array}{l}\text { Dominicus Gundisalvi: } \\
\text { vocabulary from Gerard's isolated text } \\
\text { vocabulary from Gun- } \\
\text { ground }\end{array}$ \\
& $\begin{array}{l}\text { disalvi's isolated text } \\
\text { untypical of Gerard in } \\
\text { the common ground }\end{array}$ \\
\hline
\end{tabular}

$(3 / 1)$, topicis $(2 / 1)$, syllogistici $(2 / 1)$, penetrabiliores $(2 / 1)$, rationalibus $(2 / 1)$, administrentur $(2 / 1)$, quorum proprietas (9/1), quibus rebus $(8 / 2)$, in civitatibus $(7 / 3)$, in summa $(4 / 3)$, dictionum significantium $(2 / 1)$, deinde inquirit (3/1), non erret (3/1), sciat quibus (3/1), in sermonibus (3/1), sit modus (3/1), deinde comprehendit (2/1), sicut proportio (2/1), quorum proprietas est (7/1), proprietas est ut (7/1), in civitatibus et $(4 / 3)$, consuetudines et habitus $(4 / 1)$, ad illud quod (3/2), et sermones quidem (3/1), et quibus rebus $(3 / 1)$, deinde inquirit de $(2 / 1)$, et illa quidem $(2 / 1)$, in utrisque rebus $(2 / 1)$, ut non erret $(2 / 1)$, sit modus in $(2 / 1)$, est ut administrentur $(2 / 1)$, ensis ad ensem (2/1), suam efficit operationem (2/1), operationes et consuetudines (2/1), quorum proprietas est ut (5/1), in civitatibus et gentibus $(2 / 3)$
Isaac Israeli, reliquarum $(3 / 1)$, firmat $(3 / 2)$, vivo $(2 / 1)$ On Definitions falso $(2 / 1)$, intellectualiter $(2 / 1)$, post quietem $(7 / 1)$, exitum eius $(3 / 1)$, scientiam totius $(2 / 1)$, definierunt eam $(2 / 1)$ effectum $(3 / 2)$

In the common ground of the two translations of Alfarabi's De scientiis, there is overwhelming evidence for terms and phrases of Gerard of Cremona that are untypical of Gundisalvi. This is very clear evidence that Gerard was the first to translate De scientiis into Latin and that Gundisalvi revised the translation by thoroughly rewriting some passages, while leaving other passages untouched. 
In the case of Isaac Israeli's On Definitions, there is also a good number of Gerardian phrases in the common ground, but only one Gundisalvian phrase. This makes it likely that Gerard's translation was first, and that this is indeed the case will be shown in the third step below. The vocabulary of Alkindi's On the Intellect, on the other hand, does not yet offer us any clues.

(3) In a third step, the textual basis for stylistic analysis is narrowed down again. The search is now for phrases in the common ground that appear also in the isolated versions of Gerard or Gundisalvi, regardless whether they are employed elsewhere by the two translators. The idea is to single out all those phrases that appear in the common ground, but only in one of the two isolated versions, that is, either in Gerard's or Gundisalvi's version. For this purpose, single words are ignored because their number is too massive. Two-word phrases with $e t$ are not recorded either. Moreover, only those phrases are considered which appear at least two times in an isolated version for Alkindi and Isaac Israeli. In the case of Alfarabi's De scientiis, there is so much material already for phrases appearing at least three times that I do not record phrases that appear two times. The result is the following:

Gerard's three versions compared against Gundisalvi's three versions

\begin{tabular}{|c|c|c|}
\hline & $\begin{array}{l}\text { Gerard of Cremona: } \\
\text { stylistic evidence from Gerard's isolated } \\
\text { text in the common ground }\end{array}$ & $\begin{array}{l}\text { Dominicus Gundisalvi: } \\
\text { stylistic evidence from } \\
\text { Gundisalvi's isolated } \\
\text { text in the common } \\
\text { ground }\end{array}$ \\
\hline $\begin{array}{l}\text { Alkindi, On } \\
\text { the Intellect }\end{array}$ & $\begin{array}{l}\text { ex parte ( } 2 \text { occ. in Gerard's isolated text } / 2 \\
\text { occ. in the common ground) }\end{array}$ & $\begin{array}{l}\text { est in }(4 / 5), \text { in anima } \\
(3 / 13), \text { quod est }(2 / 4)\end{array}$ \\
\hline $\begin{array}{l}\text { Alfarabi, On } \\
\text { the Sciences }\end{array}$ & $\begin{array}{l}\text { ex eis }(24 / 8) \text {, sunt in }(19 / 7) \text {, in quibus } \\
(15 / 3) \text {, est possibile }(15 / 1) \text {, est sicut }(12 / 2) \text {, } \\
\text { ab eis }(10 / 3) \text {, in lineis }(10 / 1) \text {, proprietas est } \\
(10 / 2) \text {, de eis }(9 / 1) \text {, est illa }(9 / 1) \text {, in omnibus } \\
(9 / 1) \text {, quorum proprietas }(9 / 1) \text {, est verum } \\
(8 / 1) \text {, quibus rebus }(8 / 2) \text {, in omni }(7 / 1) \text {, ad } \\
\text { illud }(7 / 3) \text {, quod sunt }(7 / 7) \text {, in civitatibus } \\
(7 / 3) \text {, in unaquaque }(6 / 3) \text {, in ea }(6 / 3) \text {, ut } \\
\text { non }(6 / 1) \text {, ut sint }(6 / 2), \text { eis cum }(6 / 1) \text {, hoc } \\
\text { nomine }(6 / 1) \text {, ergo sunt }(5 / 1) \text {, in illa }(5 / 1) \text {, } \\
\text { secundum modum }(5 / 1) \text {, per }\end{array}$ & $\begin{array}{l}\text { est proprium }(4 / 1) \text {, de } \\
\text { dictionibus }(3 / 2) \text {, libro } \\
\text { qui }(3 / 1) \text {, ut in }(3 / 1) \text {, in } \\
\text { naturalibus }(3 / 1)\end{array}$ \\
\hline
\end{tabular}


Gerard's three versions compared against Gundisalvi's three versions (cont.)

\begin{tabular}{ll}
\hline Gerard of Cremona: & $\begin{array}{l}\text { Dominicus Gundisalvi: } \\
\text { stylistic evidence from Gerard's isolated }\end{array}$ \\
text in the common ground & $\begin{array}{l}\text { Gundisalvi's isolated } \\
\text { text in the common } \\
\end{array}$ \\
& ground \\
\hline
\end{tabular}

eas (5/3), secundum viam (5/1), ei quod (5/1), in summa (4/3), cum quibus (4/1), in esse $(4 / 1)$, in unoquoque $(4 / 1)$, quo est $(4 / 1)$, in utrisque $(4 / 1)$, in scientiis $(4 / 1)$, cum eis $(4 / 1)$, una est $(4 / 2)$, in qua $(4 / 2)$, est eius (4/2), corporum naturalium (4/1), dictionum significantium (3/1), dictionum simplicium (3/1), deinde inquirit $(3 / 2)$, in fine $(3 / 1)$, an sint $(3 / 6)$, eis quod $(3 / 1)$, dat regulas $(3 / 5)$, secunda est $(3 / 2)$, eam apud (3/1), ex quo (3/2), in sententiis $(3 / 1)$, non erit $(3 / 2)$, non erret $(3 / 1)$, in anima (3/6), sermones quidem (3/1), a quo $(3 / 2)$, sciat quibus $(3 / 1)$, in sermonibus $(3 / 1)$, de omnibus $(3 / 2)$, accidunt eis $(3 / 4)$, sit modus $(3 / 1)$, eorum in $(3 / 1)$, eis per $(3 / 1)$, quod est in (11/5), illud quod est $(5 / 3)$, in civitatibus et $(4 / 3)$, consuetudines et habitus $(4 / 1)$, in quo est (3/1), ad illud quod (3/2), estverum et $(3 / 1)$, et sermones quidem $(3 / 1)$, et quibus rebus (3/1), ad invicem et (3/1), quorum proprietas est ut (5/1), quod non est verum $(4 / 1)$

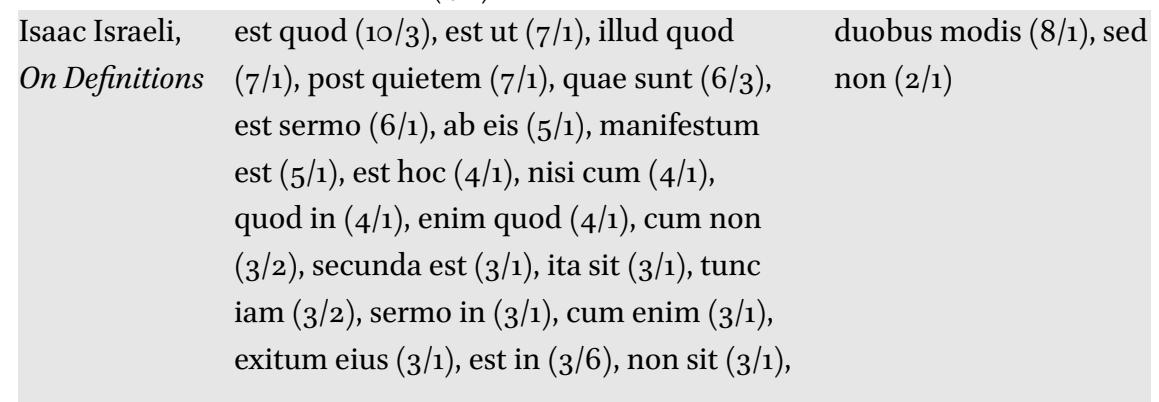


Gerard's three versions compared against Gundisalvi's three versions (cont.)

Gerard of Cremona:

stylistic evidence from Gerard's isolated text in the common ground
Dominicus Gundisalvi: stylistic evidence from Gundisalvi's isolated text in the common ground

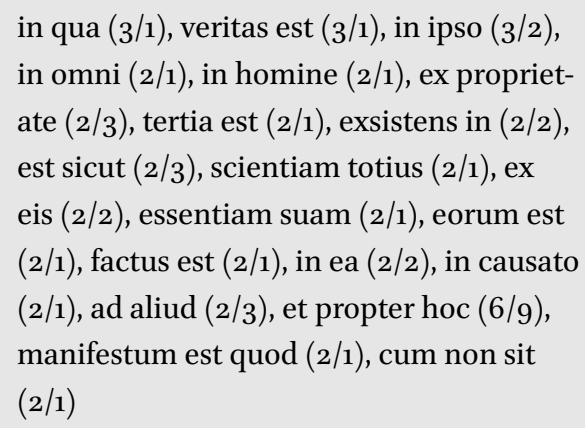

While the evidence for Alkindi's On the Intellect remains inconclusive, the comparison of the isolated versions against each other leaves no doubt about the priority of Gerard's translations of Alfarabi's On the Sciences and Isaac's On Definitions. The common ground of Alfarabi and Isaac is full with vocabulary from Gerard's isolated version, but it hardly ever resonates with the vocabulary of Gundisalvi's isolated version. Apparently, Gundisalvi left much material in these two translations intact when revising Gerard's version.

In order to know more about Alkindi's On the Intellect, we have to return to the close reading of the text which we started above when analyzing the usage of ex parte and secundum quod sunt. Another noteworthy difference between the two versions is Gerard's and Gundisalvi's rendering of the Arabic waqa'a tahta, 'falling under', i.e., the senses or the intellect. Gerard translates with cadere sub, Gundisalvi with subiacere:

\section{Gerard of Cremona}

Anonymous (Gundisalvi)

dixit enim

Aristoteles

quod forma est duae formae quarum una est habens materiam et

illa 
(cont.)

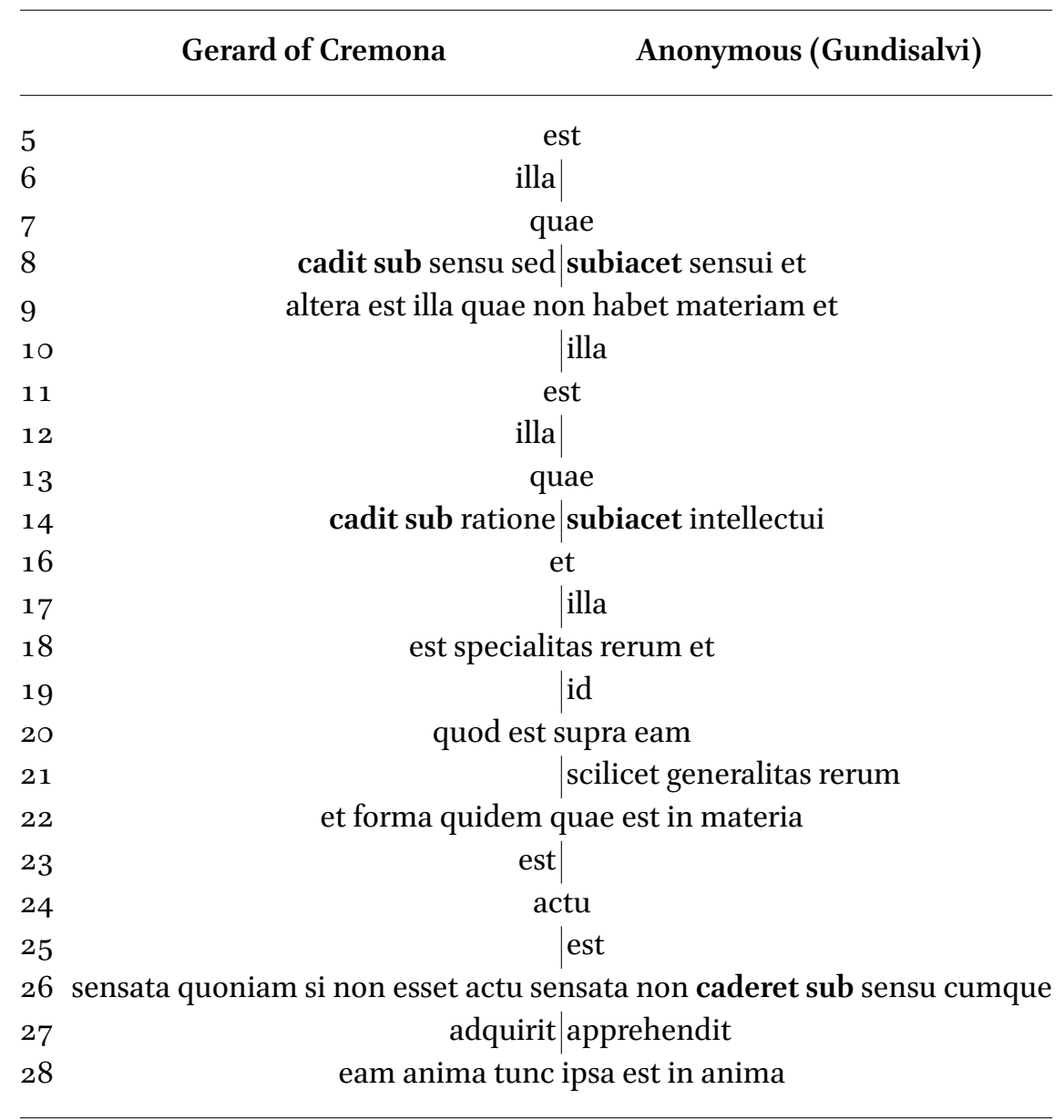

This passage again speaks in favour of Gerard being the first translator and Gundisalvi being the reviser. For Gerard's phrase cadere sub is once retained in the common ground (line 26). The most natural explanation is that Gundisalvi twice changed the text into subiacet, but once left it untouched. Particularly telling is the three-word phrase cadere sub sensu for Arabic waqa'a tahta al-hiss, 'falling under the senses', which Gerard also uses in line 8 (cadit sub sensu). This phrase is highly distinctive of Gerard of Cremona in all Arabic-Latin translation literature, as far as I can see by searching through the Arabic and Latin Gloss$a_{r y}{ }^{27}$ and the Arabic and Latin Corpus on the University of Würzburg website.

Hasse et al. 2009-. 
At present, I only know the phrase from Gerard's translations of the Liber de causis (where it appears twice), of Aristotle's De caelo (1) and of Alkindi's De quinque essentiis (1). It is highly probable, therefore, that Gerard is the author of the common ground and thus of the first translation of Alkindi's On the Intellect.

Another example of Gerardian language left untouched in the common ground is the phrase inventus/-a/-um est, which translates the Arabic mawğüd, 'existing. The translation of this Arabic term with forms of inveniri is motivated by the literal meaning of the root wağada, which means 'to find', 'to encounter'. This translation of mawğ $\bar{u} d$ is non uncommon in the Middle Ages, as is recorded in the Arabic and Latin Glossary: it is used, for example, by John of Seville, Alfred of Shareshill and the Burgos translators of Avicenna. In the present translation of Alkindi's On the Intellect, Gundisalvi translates mawğüd with forms of esse in four passages where Gerard employs inventus est. But in two passages inventus est is left unchanged. It is true that inventus est is not an exclusively Gerardian term, and, hence, the evidence is not as convincing as with cadere sub sensu. But it adds additional weight to the priority of Gerard's version.

A final example concerns the Arabic phrase matā $\check{s} \bar{a} a$, 'whenever it wants', which appears four times in our text. The first three occurrences are translated by Gerard as quando vult, cum vult and quando vult, where Gundisalvi writes quando voluerit, cum voluerit and cum voluerit. The fourth occurrence, however, is left unchanged by the reviser and appears as quando vult in the common ground. Again, this is Gerard's phrase, not Gundisalvi's.

In view of all this evidence for the common ground, which includes the highly characteristic phrase sunt res una mentioned above and the Gerardian vocabulary ex parte, cadere sub, inventus est and quando vult, it is safe to conclude that Alkindi's On the Intellect was translated first by Gerard and later revised by Gundisalvi. The case of Alfarabi's On the Sciences and Isaac's On Definitions is even more definite: given the enormous amount of Gerardian vocabulary in the common ground and the dearth of Gundisalvian vocabulary, even if we consider the isolated Gundisalvi versions, one can conclude with great certainty that Gerard's renderings of Alfarabi's and Isaac's text were first.

After all this, we are in a better position to answer the question of whether Gerard's translation of the Liber de causis was revised by Gundisalvi. We have learnt from the three examples of double translation that Gundisalvi is a thor- 
ough reviser of Gerard's translations - to an extent that we can still recognize his style in the revision. Is this the case too with the Liber de causis, in the form edited by Adriaan Pattin?

As to the style of Gerard of Cremona himself, there are many phrases distinctive of him in the Liber de causis translation. If the translation had been anonymous, we would have had no problem assigning it to Gerard of Cremona. Among those stylistic phrases of two words or more which serve to distinguish Gerard's translations from Gundisalvi's and which appear in at least $80 \%$ of his philosophical translations and at least 10 times, the following are in the Liber de causis: et ipsius (3), inter utraque (1), per hunc (1), quoniam quando (1), similiter quando (1), et propter illud (3), et nos quidem (3), et causa in (1), eius et ipsius (1), et illud quidem ( 1$)$. These terms contribute to the very "Gerardian sound" of the translation.

As to Gundisalvi, the probability that he revised the Liber de causis can be estimated best if we compare the traces of his vocabulary in the Liber de causis translation with the traces in the three double translations discussed above. For this purpose, I have searched for Gundisalvian phrases of two words and more which differentiate Gundisalvi's translations from Gerard (not from the other twelfth-century translators) and which appear in at least $80 \%$ of his philosophical translations and at least 10 times:

Gundisalvi's vocabulary differentiated from Gerard's vocabulary

\section{Dominicus Gundisalvi}

stylistic phrases found regularly and often in Gundisalvi's translations, but not in Gerard's ${ }^{28}$

Alkindi, De intellectu quantum ad (1), et id (1), non erat (1), est in potentia (2), et id et intellecto quod (1), quod est in potentia (1)

(length: 805 words)

Alfarabi, De divisione

et ideo (1), et deinde (1), ob hoc (2), nec in (3), alio modo (1), scientiarum (length: 69oo words) vel ex (1), et ob (2), ad illam (1), eorum non (1), hoc totum (2), id de (1), autem fuerint (1), omnibus illis (1), modo in (2), et multa (3), et ob hoc (2), si autem fuerint (1), ut per hoc (1), et hoc totum (2), et haec sunt (1)

28 The Gundisalvian terms are listed in decreasing frequency of occurrence in his oeuvre for two-word, three-word and four-word phrases respectively. 


\section{Dominicus Gundisalvi \\ stylistic phrases found regularly and often in Gundisalvi's translations, but not in Gerard's}

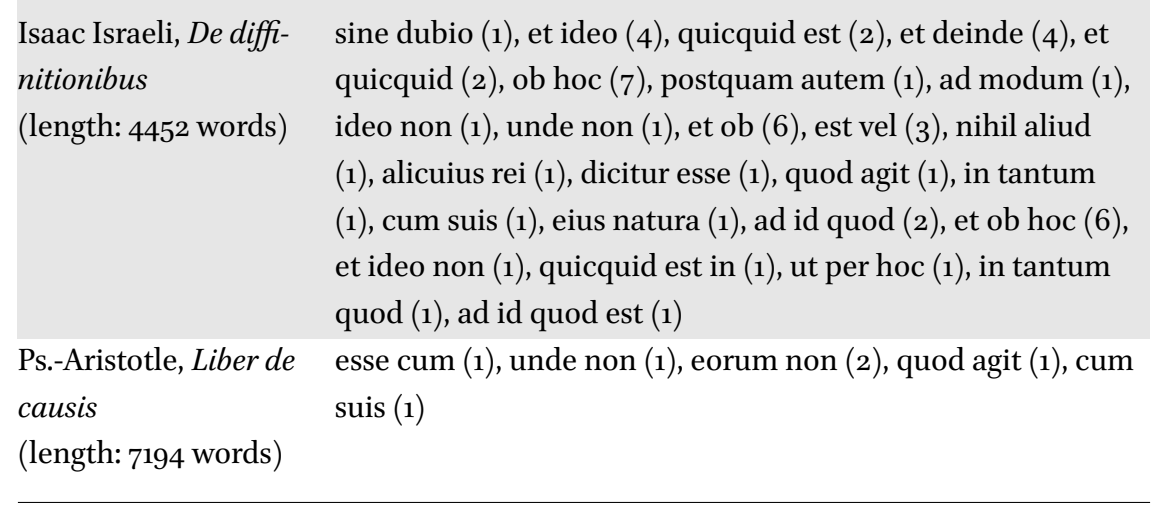

We can see here that Gundisalvi's style remains recognizable in his revisions. In the translations of Alfarabi and Isaac Israeli, one can find very distinctive threewords phrases such as et ob hoc or in tantum quod. And even the very short text On the Intellect by Alkindi contains some phrases that clearly distinguish the revision from Gerard's version. The Liber de causis, in contrast, is longer than even Alfarabi's On the Sciences (in Gundisalvi's version), but contains only some stray traces of Gundisalvian vocabulary. If Gundisalvi had revised the text in a way similar to the other three revisions, he would have left many more stylistic traces in such a long text. It is therefore very unlikely that Gundisalvi revised the Liber de causis.

\section{Bibliography}

\section{Primary Sources}

Al-Fārābī, De scientiis (I): De scientiis secundum versionem Dominici Gundisalvi. Über die Wissenschaften. Die Version des Dominicus Gundissalinus, ed. J.H.J. Schneider, Freiburg im Breisgau, Herder, 2006.

Al-Fārābī, De Scientiis (I.a), Domingo Gundisalvo: De scientiis, compilación a base principalmente de la Maqāla fù ị̣șā’ al-'ulūm de al-Fārābū, ed. M. Alonso Alonso, Madrid / Granada, Consejo superior de investigaciones cíentificas, 1954.

Al-Fārābī, De scientiis (II): Le De scientiis Alfarabii de Gérard de Crémone. Contribu- 
tion aux problèmes de l'acculturation au XIIe siècle, édition et traduction du texte A. Galonnier, Turnhout, Brepols, 2016.

Al-Fārābī, De scientiis (II.a): Über die Wissenschaften-De scientiis: Nach der lateinischen Übersetzung Gerhards von Cremona, transl. F. Schupp, Hamburg, Meiner, 2005 .

Al-Kindī (Alkindi), Rasāìl falsafiyya, ed. M.'A. Abū Rīda, Cairo, Dār al-Fikr al-Arabī 1950-1953 (repr. Frankfurt am Main, 1999).

Avicenna, Liber de anima seu Sextus de naturalibus, 2 vols, ed. S. van Riet, Louvain/ Leiden, Éditions orientalistes / Brill 1968-1972.

Dominicus Gundisalvi, De divisione philosophiae: Lateinisch/Deutsch, Über die Einteilung der Philosophie, transl. A. Fidora, D. Werner, Freiburg im Breisgau, Herder, 2007. Isaac Israeli-see Altmann, Stern $195^{8}$.

\section{Secondary Sources}

Adamson, P. (2007), Al-Kindī, Oxford, Oxford University Press.

Al-Fārābī, Arabic-Latin writings on music in the Ihṣā̄ al-ulūm (Escorial Library, Madrid, No. 646), De scientiis (British Museum, Cott. Ms. Vesp. B.X., and Bibl. Nat., Paris, No. 9335), and De ortu scientiarum (Bibl. Nat., Paris, No. 6298, and Bodleian Library, Oxford, No.3623), etc., ed. H.G. Farmer, New York, Hinrichsen Edition, 196o.

d'Alverny, M.-Th. (1994), Avicenna Latinus: Codices, Louvain-la-Neuve/Leiden, Peeters/ Brill.

d'Ancona, C., Taylor, R. (2003), 'Liber de causis', in R. Goulet (ed.), Dictionnaire des philosophes antiques, Supplément, Paris, CNRs Editions, p. 599-647.

Altmann, A., Stern, S.M. (1958), Isaac Israeli: A Neoplatonic Philosopher of the Early Tenth Century: His Works Translated with Comments and an Outline of his Philosophy, London, Oxford University Press.

Alonso Alonso, M. (1954)—see Al-Fārābī, De scientiis (I.a).

Burnett, Ch. (2001), 'The Coherence of the Arabic-Latin Translation Program in Toledo in the Twelfth Century', in Science in Context 14, p. 249-288.

Farmer, H.G. (196o)—see Al-Fārābī, On music etc.

Fidora, A., Werner, D. (2007) — see Dominicus Gundisalvi.

Galonnier, A. (2016) — see Al-Fārābī, De scientiis (II).

Hasse, D.N. (2020), 'Influence of Arabic and Islamic Philosophy on the Latin West', in E.N. Zalta (ed.), The Stanford Encyclopedia of Philosophy, Spring 2014 Edition, URL: https://plato.stanford.edu/archives/fall2O2o/entries/arabic-islamic-influence/

Hasse, D.N. together with K. Fischer, S. Gsell, S. Hvezda, B. Jockers, R. Kiesler, E. Sahr and J.O. Schmitt (eds.) (2009-), Arabic and Latin Glossary, UR L: http://algloss.de.dariah .eu.

Hasse, D.N., Büttner, A. (2018), 'Notes on Anonymous Twelfth-Century Translations of Philosophical Texts from Arabic into Latin on the Iberian Peninsula', in D.N. Hasse, 
A. Bertolacci (eds.), The Arabic, Hebrew and Latin Reception of Avicenna's Physics and Cosmology, Berlin, deGruyter, p. 313-369.

Jolivet, J. (1988), 'The Arabic Inheritance', in P. Dronke (ed.), A History of Twelfth Century Western Philosophy, Cambridge, Cambridge University Press, p. 113-150.

Lemay, R. (1978), 'Gerard of Cremona', in Ch.C. Gillespie (ed.), Dictionary of Scientific Biography. Supplement I, New York, Charles Scribner's Sons, p. 173-192.

Muckle,J.T. (1937-1938), 'Isaac Israeli: Liber de definitionibus', in Archives d'histoire doctrinale et littéraire du Moyen Âge 12-13, p. 329-340.

Muckle, J.T. (1940), 'The Treatise De anima of Dominicus Gundissalinus', Mediaeval Studies 2, p. 23-103.

Nagy, A. (1897), Die philosophischen Abhandlungen des Ja'qūb ben Ishāa al-Kindī, Münster, Aschendorff.

Pattin, A. (1966), 'Le Liber de causis', in Tijdschrift voor Filosofie 28, p. 90-203.

Polloni, N. (2016), 'Gundissalinus and the Application of al-Fārābī's Metaphysical Programme: A case of Philosophical Transfer', in Mediterranea. International journal for the transfer of knowledge 1, p. 69-106.

Rudolph, U. (2012), Philosophie in der Islamischen Welt, Band 1, 8.-10. Jahrhundert, Zürich, Schwabe Verlag.

Schneider, J.H.J. (2006) — see Al-Fārābī, De scientiis (I).

Schupp, F. (2005) — see Al-Fārābī, De scientiis (II.a).

Taylor, R.C. (1988), 'Remarks on the Latin Text and the Translator of the Kaläm fìmahd al-khair / Liber de causis', in Bulletin de philosophie médiévale 30, p. 75-102.

Van Riet, S. (1968-1972)—see Avicenna latinus.

Weber, M.C. (2002), 'Gerard of Cremona: The Danger of Being Half-Acculturated', MedievalEncounters 8, p. 123-134. 